\title{
Viral vector delivery of Env trimer immunogens
}

\author{
CL Parks", S Rabinovich, PJ Tiberio, KJ Wright, M Yuan, MG Delboy, M Kemelman, AJ Wilson, RL Powell, \\ S Hoffenberg, MJ Chiuchiolo, C Boggiano, G Morrow, IC Lorenz, CK Jurgens, X Zhang, RW Lindsay, WC Koff, \\ CR King, MJ Caulfield
}

From AIDS Vaccine 2012

Boston, MA, USA. 9-12 September 2012

\section{Background}

Our objective is to develop viral vaccine vectors that will elicit neutralizing antibodies that are specific for the functional attachment protein on the HIV particle. To achieve this goal, we are developing vectors that express membrane-anchored Env trimers that closely mimic authentic functional glycoprotein spikes.

\section{Methods}

We are using vesicular stomatitis virus (VSV) as a vector platform for delivery of Env immunogens as transmembrane glycoproteins. We have investigated a variety of vector designs and Env modifications to identify combinations that balance the practical requirement for vector genetic stability with factors influencing antibody responses including immunogen abundance, efficient post-translational processing, and presentation of antigenic determinants representative of a functional trimeric spike.

\section{Results}

Substituting domains in Env with analogous regions from VSV G, we have developed a number of immunogens that are efficiently expressed and incorporated in the infected cell plasma membrane, and in most cases, progeny virus particles. Antigenicity was evaluated using a panel of monoclonal antibodies specific for various Env epitopes.

\section{Conclusion}

We identified modified Env immunogens that contain determinants for most classes of known broadly neutralizing monoclonal antibodies including those with specificity for the CD4 binding site (b12, PGV04), V3 and carbohydrate (PGT126), the MPER (2F5 and 4E10), the glycan shield (2G12), and structures formed by V1/V2

International AIDS Vaccine Initiative, Brooklyn, NY, USA and carbohydrate (PG9, PG16, PGT145). Results from ongoing immunogenicity studies with vectors encoding SIV or HIV Env immunogens (subtypes A, B, or C) indicate that the modified trimers elicit antibody responses in small animals and nonhuman primates, and that some live vectors induce mucosal antibodies. Study sera are being analyzed for virus neutralization activity and fine specificity.

Published: 13 September 2012

doi:10.1186/1742-4690-9-S2-P341

Cite this article as: Parks et al:: Viral vector delivery of Env trimer immunogens. Retrovirology 2012 9(Suppl 2):P341.
Submit your next manuscript to BioMed Central and take full advantage of:

- Convenient online submission

- Thorough peer review

- No space constraints or color figure charges

- Immediate publication on acceptance

- Inclusion in PubMed, CAS, Scopus and Google Scholar

- Research which is freely available for redistribution
() Bïomed Central
() 2012 Parks et al; licensee BioMed Central Ltd. This is an Open Access article distributed under the terms of the Creative Commons Attribution License (http://creativecommons.org/licenses/by/2.0), which permits unrestricted use, distribution, and reproduction in any medium, provided the original work is properly cited. 